\title{
The Car as Avatar in Australian Social Security Decisions
}

\author{
Kieran Tranter $^{1}$
}

\begin{abstract}
This paper draws upon automobile semiotics and legal semiotics to argue that the car in Australian social security decisions becomes an avatar for the applicant that is then decoded into meaning streams concerning deservingness and prudence. It is suggested that this has two implications. The first it highlights the techniques where by a technical object (the car) and the 'life' of the applicant became bridged in law; and through that bridging life becomes 'formatted.' The second highlights the extent of automobile culture. The car has meaning beyond the highways and parking lots. The paper shows how these meanings have become integrated into processes of biopolitical governance.
\end{abstract}

\section{Keywords}

Automobility; Automobile Semiotics; Avatar; Biopolitics; Deservingness; Australian Social Security Law

\footnotetext{
${ }^{1}$ Kieran Tranter, Senior Lecturer, Griffith Law School. I would like to thank Emma Wagstaff for her research assistance. A draft of this paper was presented at the Faculty of Law, University of Otago in July 2013 and I thank faculty members for their comments and insights. Nevertheless, all errors, omissions and oversights are my own. Correspondence: k.tranter@griffith.edu.au, Gold Coast campus Griffith University, Queensland, 4222, Australia. Telephone +64 755528161 . Facsimile +64 755528667.
} 


\section{Introduction}

Central to the idea of automobility has been the full integration of motor vehicles into human life [125: 26, 8: 4]. To study automobility was not to be limited to the obvious economics of transport, the logistics of urban planning or the rules of roads but opened to other, less obvious, spaces of identity, gender and even grief $[113,38,26,33]$. Bringing together automobility and law is not just an opportunity to explore the politics of highway policing or regulation of risk in vehicle design, but a chance to map the depth and totality of the ways that the car has integrated into human life.

This paper shows the merging of the human and motor vehicle through exposing the depth and significance of meaning attached to cars within Australian social security law. It is argued that the car is not just an asset whose monetary value goes towards tests for eligibility, but within the decisions the car becomes an avatar for the applicant that is decoded into meaning streams concerning deservingness and prudence.

This paper is in three stages. The first stage sets the scene, introducing 'automobility and law' and social security review decisions by the Commonwealth of Australia's Administrative Appeals Tribunal (AAT). The second stage sets out the findings of an analysis of 145 AAT social security decisions that discussed the motor vehicles associated with an applicant. The car as avatar for the applicant will be identified and the process whereby the AAT's working of social security law decodes the car avatar into meaning streams concerning deservingness and prudence will be identified. The third stage returns these findings to law and automobility. For law what become apparent are the techniques where by a technical object (the car) and the 'life' of the applicant become bridged in law. For automobility, what emerges is the extent that the car is a bearer of meaning. The semiotics of automobile culture has leached from the highways into other processes of biopolitical governance.

\section{Setting the Scene}

In 1905 Xenophon P. Huddy wrote in the Yale Law Review about the legal ramifications of the emerging automobile [32]. His concern was not merely academic. Throughout the West the preWorld War I period was characterised by widespread public concern with the rights and responsibilities of drivers of motor vehicles [24, 44, 34]. By the outbreak of the war many 
jurisdictions had introduced specific motor vehicle laws, of various degrees of sophistication, dealing with the registration, licencing, road rules and criminal conduct associated with cars [122]. At this early stage law and the motor vehicle were closely intertwined. This intertwining continued. Between the wars and then in the post-World War II period the motor vehicle became the subject of specific legal discourses concerning liability for personal and property damage, vehicle design, town and road planning, pollution control and the regulation, and criminalisation of automobile related conduct. Most jurisdictions introduced complex legislative regulatory regimes, specific motor vehicle criminal offences and case law explored the application of established principles, concerning duty and liability and of promises and representations, to new forms of motor vehicle mediated activity. As more and more space in Western cities became designated for the car $[39,9,17]$, so to more and more of Western law became, directly and indirectly, related to the motor vehicle and the forms of mobility that it allowed. The level of integration of the motor vehicle into law can be seen in the Australian law report series Motor Vehicle Report which since 1983 has published superior court decisions 'concerning traffic accidents, licensing of vehicles, duties of highway authorities, criminal procedure for traffic offences, civil procedure relating to negligence and statutory claims for insurance' [36].

Recent study and theorising about the automobile has become inspired by John Urry's notion of automobility. Urry provided a framework through which to explore human-automobile interactions. Urry urged social science and social theory to examine the nexuses that make automobility a 'system' [125: 26]. He emphasised multiple layers ranging from the social and cultural concerns of driver identity to the micro-and macro-economics of the automobile to the technical discourses of design and construction [125: 25-26]. Following Urry there has been a flourishing of studies of automobility $[8,23,25,39,41,115]$. One aspect of automobility that has not been fully pursued within this literature has been law [123: 1-2]. ${ }^{2}$ While the intimate history of law and motor vehicle means that law can be identified as an implicit factor within many automoblity studies, it is the express focus on 'law and automobility' that this paper pursues.

It does so at a not so obvious level. Thinking 'law and automobility' would suggest a consideration of the direct sites of intersection of the law and the motor vehicle such as policing of the roads, liability allocation and planning. However, Urry's 'automobility' urges exploration of less direct interconnections of the automobile on governance, cultural and social practices. It is in this spirit of automobility that this paper focuses on an interconnection of law and automobiles; the traces of automobiles within Australian social security appeal decisions. Before this can be done

\footnotetext{
${ }^{2}$ There is a small literature exploring law and automobility, see $[37,127]$.
} 
some further introduction to the Australian social security regime and the appeal structures requires explanation.

The Social Security Act 1991 (Cth) provides the legislative machinery for a comprehensive system of income support payments to be paid by the Australian Commonwealth government to citizens and residents who meet specific eligibility requirements. There are a significant range of payments directed to different groups within the community. The major payments are Age Pension, paid to eligible persons over 65 years of age, Newstart Allowance, paid to unemployed persons who are actively looking for work, Disability Support Pension, paid to persons who have a significant disability and are unable to work or undertake training, Youth Allowance, paid to young people aged 16-25 who are looking for work or undertaking education and Single Parents Payment, paid to a person who has sole care and responsibility for a child under a specific age [18]. In 2013 the administrating department is called the Department of Human Services. There are several other features of the system. The first is that all payments are subject to asset and income tests. These tests determine that an applicant who would otherwise be eligible would not receive a payment if their assets and/or income from other sources exceed prescribed limits [10: 71-72]. This introduces complexity into the administration of the Act and a significant portion of the Social Security Act 1991 (Cth) is devoted to technical provisions concerning how to identify assets and income. Another feature of the system is a distinction between 'single' applicants and 'partnered' applicants. An applicant with a 'partner' receives a less rate of payment and the assets and income of the partner are considered when considering the applicant's assets and income [116]. Since reforms in 2008 applicants in same sex relationships have been considered partnered [118: s 4(2)].

The Social Security (Administration) Act 1999 (Cth) establishes a system of administrative appeal from a primary determination by an officer in the Department. There is a four tier appeal process involving two levels of internal appeals within the Department [117: ss 124Q-138] and then an appeal to a specialist external tribunal, the Social Security Appeals Tribunal [117: ss 139-177D]. If the Department or the applicant disagrees with the decision of the Social Security Appeals Tribunal there is a final avenue of appeal to the Administrative Appeal Tribunal (AAT) [117: ss 178-187]. The AAT was established in 1975 to provide a general administrative review tribunal across a range of Commonwealth legislation [3]. With the express purpose of providing 'fair, just, economical, informal and quick' administrative justice [3: s 2A], the AAT has developed into a rather formal, court-like entity [4: 22]. Its hearings are held in public, its written reasons for decisions are made publically available, the hearing process involves witness testimony and cross-examination and often parties before it are legally represented. However, unlike courts which can only declare an 
administrative decision unlawful, the AAT 'stands in the shoes' of the original decision-maker [114: Kiefel J 322]. This means that the AAT remakes the original decision based on the evidence presented at the hearing and the archive of evidence that has built up around the matter as it progressed through the earlier appeal stages [114: Kirby J 299-300]. As such its decisions provide direct insight into 'every-day' decision-making of a particular area of law onto the lives individuals. It is this window into law's everyday judging and ordering of life that allows decisions of the AAT to be examined as a site for law and automoblity.

\section{The Car as Avatar for the Australia Social Security Applicant}

This study examined 145 decisions of the AAT concerning the application of the Social Security Act 1991 (Cth) that involved discussion of motor vehicles. The sample ranged from decisions from 1998 to 2012. Decisions of the AAT are publically available via the Australasian Legal Information Institute (AustLII) website [6]. A feature of the AustLII site is full-text searching of the decision in the database. This meant that there could be targeted identification of relevant decisions through a repeat series of searches using the key words 'social security' in combination with motor vehicle manufacturers names that have been in the Australian market. Also used were generic terms like 'car' and 'motor vehicle'. Once identified the decision was examined to ensure that it was a social security decision that mentioned a motor vehicle.

It is important to note that this sample of 145 is only a small percentage of all AAT social security decisions made between 1998 and 2012. In the 2011-2012 reporting period the AAT finalised 1,430 social security applications [2: 23] and in earlier reporting periods, such as 2009-2010, the caseload has been as high as 2,077 [1: 21]. So while motor vehicles are mentioned in social security decisions, it is not an overtly frequent or regular occurrence.

Some basic features of the sample are worth noting. The first is which party appealed to the AAT. In the sample $80 \%(116 / 145)$ of decisions were applicant appeals and 20\% (29/145) were Department appeals. This seems above the average. In 2011-2012 only $2.7 \%(39 / 1,432)$ were Department appeals, raising the suggestion that somehow the Department is not satisfied with how the Social Security Appeals Tribunal deals with matters involving motor vehicles. The second feature is the payments under review. As the decisions in the sample often concerned an applicant's eligibility for payments over a period of time some decisions recorded more than one payment. However, there was significant clustering concerning the payments within the sample. 75 decisions 
involved Disability Support Payment, 24 decisions involved Newstart Allowance, 22 Parenting Payment, 18 Aged Pension, 4 Sickness Allowance and 13 miscellaneous payments - including Carers Payment and Child Care Benefit.

There was also significant clustering as to the sort of issues that were the subject matter of the decision. 59 decisions concerned the 'preclusion period' applied to an applicant who had received a lump sum compensation payment. The preclusion period rules calculate a period of time that an applicant is not eligible for social security. The underlying policy is that the compensation payment would include an amount for loss of future income and the applicant should live off that amount for a reasonable period before they can access a social security payment [120: 501] Specifically most of these decisions concerned whether there were 'special circumstances' to waive the preclusion period under s1184K of the Social Security Act 1991 (Cth). ${ }^{3}$ The phrase 'special circumstances' was also a feature of another 20 decisions where the issue was whether a debt or overpayment should be waived. ${ }^{4} 31$ decisions in the sample were determinations of whether the applicant was a 'member of a couple' as defined under s 4(3) [for example [70] and [109]]. 9 decisions concerned 'mobility.' These 9 decisions primarily involved whether the applicant's disability prevented them from driving [for example [47] and [68]]. Finally 19 decisions concerned the applicant's car as an asset or as evidence of income. These decisions involved disputes as to the correct valuation to be placed on vehicles [for example [91]] or whether the applicant was deriving income from the buying and selling of vehicles [for example [98]].

The final basic feature of the sample is the actual motor vehicles mentioned in the decisions. These are set out in table 1 in the Appendix. Many decisions involved multiple vehicles explaining why there are 216 vehicles listed. The table of raw scores tells a limited story. The first is that the top five ranked manufactures, Toyota (40), Ford (34), General Motors Holden (34), Nissan (14) and Hyundai (12) corresponds with the breakdown of vehicles by manufacturer in official censuses of the Australian motor vehicle fleet [7: 15]. Together these manufacturers accounted for $62 \%(134 / 216)$ of the vehicles in the sample. In this the sample could be seen as reflecting the general ownership patterns of motor vehicles in Australia. However, care needs to be taken when considering table 1. The list of manufacturers covers their full line-up of vehicles from light cars through to large SUVs and does not provide details on the age or condition of the vehicle. ${ }^{5}$ For example vehicles counted in the Toyota score ranged from a 15 year-old Corolla small car [79] to a brand new, $\$ 60,000$ (in 2003)

\footnotetext{
${ }^{3}$ In the sample 40 decisions concerned s1184K. For example [81, 63].

${ }^{4}$ In the sample the sections concerning waiver of an overpayment are ss 1236-1237AAD. For example [61, 90].

${ }^{5}$ Some decisions provided a clear description of the vehicle, including make, model, age, condition and initial purchase price and likely market valuation. In other decisions less description was available.
} 
Land Cruiser large SUV [100]. Another feature in table 1 is that there seems to be a conspicuous number of vehicles from prestige manufacturers. Mercedes Benz (7), BMW (5), Rolls Royce (3), Range Rover (1) and Porsche (1) comprise 7.8\% (17/216) of the sample. This immediately suggests a response around the notion of deservingness. It triggers the same set of meanings that North America conservative do with their imagery of the 'welfare queen' driving a Cadillac [42, 11: 1692]. That is the social security system should not be supporting the owners of prestige cars and if an applicant does have a prestige car and receives social security then it is evidence of either their rorting a loophole in the system or blatant fraudulent behaviour. There are two unarticulated assumptions in this response. The first is that the vehicle is new and expensive. The second is that ownership of this new and expensive vehicle evidences significant means, either in the form of an asset of considerable worth that could be sold allowing the applicant live off the proceeds, or undisclosed income which had facilitated the purchase of the vehicle. These can be rebutted by the details in the individual decisions. In Re Douglas Doelle and Secretary, Department of Family, Housing, Community Services and Indigenous Affairs the applicant's Mercedes Benz was 31 years old [57: Karas SM [7]]. The Porsche in the sample was 18 years old and valued at the most at $\$ 15,000$ [62: Sweidan SM [60]]. ${ }^{6}$ These actuality of old cars of not exceptionally high value are not the images immediately conjured by the association of a social security applicant and a vehicle from a prestige marque.

It is this conjuring that is precisely what is interesting in the sample. Motor vehicles are the bearers of cultural meaning [29: 158]. Cultural approaches to automobility have identified that Australians communicate identity, gender, age, wealth and status through the car that they drive. ${ }^{7}$ Motor vehicles are signs that carry diverse signification [21, 43]. Studies in automobile semiotics have revealed that cars are not just means of transportation but highly invested sites of identity, consumption and communication [28, 31,30]. Recent cultural work on virtual environments has introduced the idea of the avatar to wider scholarship. The avatar represents the user within a constructed world; but not necessarily in a linear or photorealistic way. The avatar - how they look, the gender, species, size, colour - is 'chosen' by the individual; a choice that is often constrained by the resources within the virtual environment $[12,13]$. An individual constructs their avatar in the knowledge that their avatar would be 'decoded' by other denizens of the virtual world to make various assumptions about the user behind the avatar ranging from their gender and age to their

\footnotetext{
${ }^{6}$ The valuation was based on a 2002 registration record. This date is 6 years earlier than the date of the decision. At the time of the decision the Porsche would be a third older and it would be reasonable to expect had further decreased in value.

${ }^{7}$ [121]. I make no claims that this semiotics of automobility is unique to Australians. The Cadillac owning welfare Queen is evidence that such a symbolic economy surrounds the motor vehicle in other national cultures. See Clarsen $[14,15]$ on national cultures of automobility.
} 
experience within the virtual world $[22,16]$. It has been suggested that the car as a complex sign performs an avatar function [40: 92-93]. The car as avatar allows a projection of self and also a knowing of others within the constructed reality of highways and parking lots of the modern West $[31: 6-17,43,20]$.

What the sample shows is the car avatar and its semiotic fields do not just circulate on the suburban grids but have been transposed into legal discourse. The car associated with an applicant is something more than just an asset that the applicant owns or had owned. Very few of the decisions concerned the base mechanics of determining the value of the applicant's automotive property. One of these few was Re Robin Phillips and Secretary, Department of Families, Housing, Community Services and Indigenous Affairs where the AAT was tasked with determining the value of a Rolls Royce, a Ford Fairmont and a commercial van and it consulted the 'Red Book' [111] of vehicle valuations used by the Australian motor trade and insurance industries to determine their values at $\$ 14,961, \$ 19,000$ and $\$ 6,000$ [91: McCabe SM [13]].

The sample also shows that the car was considered as something more than just an indication of an applicant's mobility. In Re Peter Holt and Secretary, Department of Education, Employment and Workplace Relations the mobility limitations associated with the applicant's 29 year old Honda Accord (highly unreliable) and small 125cc scooter (unable to carry work tools) substantiated the argument that 'special circumstances' existed for paying the applicant a higher rate of Newstart Allowance [83: Creyke SM [17], [57]]. However, discussions of motor vehicles as an indicator of mobility were rare. Instead, the car circulated within the AAT decisions as a much more complicated bearer of contested meanings. The first of these is the car as avatar. In these decisions the applicant and other humans became represented by their cars and the doings of the car became attributed to or affected the applicant. Second, this car avatar was then decoded into meaning streams concerned with deservingness and prudence.

\subsection{Car as Avatar}

A significant feature within the sample was where the decision maker treated a car as an avatar for an applicant. In these decisions the division between human and automobile was erased. This primarily occurred where the issue was whether the applicant was a 'member of a couple.' In this context cars were promiscuous; they were caught on camera at certain addresses; the names of the alleged couple were together on registration, loan or insurance documents; and the movement of cars - who they carried, where, when and to - mattered. In Re Michelle Lizars and Secretary, Department of Education, Employment and Workplace Relations video surveillance that showed that the alleged partner's 1998 white Holden Commodore sedan parked at the applicant's property was 
significant evidence that she was a 'member of a couple' [77: Hotop DP [53], [55]]. In this decision the togetherness of automobile and real property represented the togetherness of the applicant and the alleged partner. What was not mentioned in the decision was whether the video surveillance actually recorded the alleged partner entering and leaving the property (one would assume in the 1998 white Holden Commodore sedan). Nor was it mentioned that the surveillance video revealed the applicant driving the surveyed motor vehicle. Instead, the presence of a motor vehicle owned by a man at the applicant's property was significant evidence that the applicant was 'partnered' and not eligible for parenting payment at the single rate. Similar was Re Secretary, Department of Families, Housing, Community Services and Indigenous Affairs and Petra Schatz where the presence of a motor vehicle owned by a man (a new Holden Monaro) at the applicant's property was evidence of a relationship [97: Hotop DP [52]]. In these decisions the car had become the alleged partner.

The material constructing the car avatar in the decisions went beyond surveillance evidence of vehicles seen at properties. In some decisions the information retrieved from searches of motor vehicle ownership and registration databases was sufficient. Here the avatar-ic nature of the car is most obvious. The car as a material thing vanished; there was no concern in these decisions with whether a vehicle in real life was regularly seen at the applicant property. Instead, the pure informatics was prioritised. For example in Re Kathryn Farrugia Steven Baltis and Secretary, Department of Employment, Education and Workplace Relations the evidence that 'Ms Farrugia and Mr Baltis did, however, jointly own vehicles' went towards finding that they were in a relationship [70: Webb M [39]]. In Re Secretary, Department of Employment and Workplace Relations and Graham Inkster and Caterina Lelasi the finding that the vehicles registered to the applicant and the alleged partner had the same address listed was considered strong evidence of a relationship [94: Tovey M [64]]. In some cases the data supported a finding of not in a relationship. In Re Silvia Rodriguez and Secretary, Department of Families, Housing, Community Services and Indigenous Affairs having the vehicles registered in sole names - even though there was evidence of each driving the others car - was evidence against a relationship [103: Cunningham SM [36]].

In some decisions the opposite occurred. Instead of the car avatar losing its materiality, the car avatar was forged through a very material mixing of humans and machines. In these decisions it was the cybernetic entity of humans in cars - precisely, evidence of the applicant driving the alleged partner's car or the other way round - that was the focus. In Re Sharon Hodges and Secretary, Department of Employment and Workplace Relations the applicant's was found to be a relationship

\footnotetext{
${ }^{8}$ In Re QDGF and Secretary, Department of Employment and Workplace Relations [84: Handley SM [63], [70]] an alleged partner purchasing a car for the applicant was evidence of a relationship. See also Re Alexandra Harvey and Secretary, Department of Education, Employment and Workplace Relations [46: Hotop DP [55]].
} 
because she was observed driving a vehicle owned by the alleged partner and bearing an advertisement for the alleged partner's business, while the alleged partner had been observed driving a vehicle registered in her name which also had signs for the alleged partner's business [102: Webb M [26], [86]]. In Re Shane Jarvis and Secretary, Department of Education, Employment and Workplace Relations surveillance videos of the alleged partner collecting the applicant's children from school in his car and taking shopping to the applicant's car evidenced a relationship [101: Kenny SM [29]]. In Re Tracey Jane Day and Secretary, Department of Education, Employment and Workplace Relations evidence of the applicant driving vehicles purchased by and registered in the name of the alleged partner established a relationship [106: Hotop DP [22], [47]].

In these three ways the car avatar was established. First, the car in its materiality was present in the decisions - it had been seen at a certain place at certain times - and the presence was attributed to a human. Second, the car lost its materiality entirety. Instead, the car's presence was an entry in a database that contained fields with the names of humans. Third, the car avatar was formed as a cybernetic entity comprised of humans in cars that was seen and recorded.

However, these car avatars were thin. The identified narratives conjured by the Cadillac driving welfare queen of deservingness was not present. Instead, the car functioned as an avatar through being an object of affect; a relational vector that connected humans. It did not seem to matter that the car was a Mercedes or Ford. What seemed to matter was the car attached to a human, either the applicant or alleged partner which then glued other humans. ${ }^{9}$ But not entirely. There was something interesting about the decisions where the female applicant was found to be in a relationship because a motor vehicle registered to a man had been observed on her property. Studies of automobility have long identified how motor vehicles have communicated gender [126]. Some cars are considered masculine and predominately associated with men; while others are seen as feminie cars marketed to and predominately associated with women [97]. In both Re Michelle Lizars and Secretary, Department of Education, Employment and Workplace Relations (Lizars) [77] and Re Secretary, Department of Families, Housing, Community Services and Indigenous Affairs and Petra Schatz (Schatz) [97] the vehicles that stood-in for the alleged partner were strongly 'masculine' cars. In Lizars the vehicle was a Holden Commodore, a full size, rear-wheel drive V6 powered sedan often associated when new as 'Dad's car' [119: 37-44] or when older as a vehicle of choice by young men for modification [114: 37-48]. In Schatz the vehicle, a Holden Monaro, a 2 door V8 powered muscle car, is one of pinnacle vehicles for Australian masculine automobile culture [112]. The decisions leave open the possibilities that if the vehicles were not so strongly indicative of a male

\footnotetext{
${ }^{9}$ On the affective orientation of the member of a couple provisions in Australian social security and the surveillance of applicants authorised by the provision see [124].
} 
presence, if they were androgynous small Toyotas for instance, then the applicant's relationship status might not have been under scrutiny. What the Holdens in Lizars and Schatz reveal is that the car avatar can be decoded into constitute meaning streams. The sort of car associated with an applicant matters. While Cadillacs have never been officially sold in Australia, the cars associate with applicants is decoded by the AAT into moral narratives of deservingness and prudence.

\subsection{Deservingness and Prudence}

The car avatar as communicating deservingness and prudence was the dominate feature of the sample. The type of car, its age and condition communicated the moral worth of the applicant. In a few decisions applicants tried to use a car avatar to establish that they deserved social security. In Re Mary Hopkins and Secretary, Department of Families, Housing, Community Services and Indigenous Affairs the applicant argued that as she drove an 'old Volvo' she lived 'frugally' and did not gain undisclosed income from an identified trust fund [75: Handley SM [32]]. In Re Wafaa Gendy and Secretary, Department of Families, Housing, Community Services and Indigenous Affairs the applicant argued that owning a 19 year old BMW was evidence of financial hardship [108: Bell SM [14]]. In Re Monica Terese Eime and Secretary, Department of Families, Housing, Community Services and Indigenous Affairs the applicant argued that being unable to repair her damaged 8 year old Nissan showed that she was in 'special circumstances.' [80: Dunne SM [11]]. In all three decisions the applicants unsuccessfully tried to connect the age, condition or value of their motor vehicle to a wider set of meanings about people in poverty. That people who deserve social security own rundown and old motor vehicles.

The link between a rundown and old motor vehicle and an applicant's deservingness of social security was often made by the AAT. In Re Stephen Thomas and Secretary, Department of Family and Community Services the applicant's 29 year old Holden utility (Australian for pickup truck) went some way to explain why his 'misfortune set him apart from the usual run of cases' [105: McCabe M [16]]..$^{10}$ In Re Rita Liszikam and Secretary, Department of Families, Community Services and Indigenous Affairs the applicants' 18 year old Toyota Corolla (valued at \$300) and 18 year old Nissan Pathfinder (valued at $\$ 2,000$ ) contributed to the AAT deciding to write off some of their social security debt [88: Christie M [55]]. Similar in Re Craig Whittier Cornish and Secretary, Department of Family and Community Services that the applicant owned a 11 year old Toyota Corolla which he was

\footnotetext{
${ }^{10}$ Similar in Re Bernard Charles Griffin-Beale and Secretary, Department of Family and Community Services [48: Pascoe SM [16]] was highly 'sympathetic' to the applicant whose only motor vehicle was a 31 year old Ford Fairlane. See also Re Brett Matthew Cashion and Secretary, Department of Family and Community Services [51: Davis M [38]] where an applicant with a 17 year old Holden ute was described 'not appear[ing] to have acted in an extravagant, frivolous or bizarre fashion when compensation monies were received.'
} 
still paying off evidenced to the AAT that he was in 'financial hardship' that amounted to 'special circumstances' to waive the debt [54: Kiosoglous SM [55-56]].

The reverse was also true. If owning an old motor vehicle evidenced that an applicant deserved social security; then evidence of ownership of a new or near new motor vehicle suggested un-deservingness. Re Milovan Nikolic and Secretary, Department of Family and Community Services the applicant's ownership of a relatively new 4 year old car valued at $\$ 12,000$ went against his getting social security. The AAT suggested that he should sell it and purchase a cheaper vehicle [78: Handley SM [20]]. Owning several motor vehicles was often conclusive evidence that the applicant did not deserve social security. In Re Secretary, Department of Families, Housing, Community Services and Indigenous Affairs and Agaton Balaj owning two motor vehicles was seen by the AAT as putting the applicants 'in a better situation than many welfare recipients' [96: Bean SM [67]]. In Re Joao De Sousa and Secretary, Department of Family and Community Services the applicant was described as in a 'considerably more fortunate financial situation than many recipients...he has many assets including two valuable motor vehicles' [66: Bell M [36]]. ${ }^{11}$

Not all decisions regarded owning two motor vehicles as evidence of un-deservingness. In Re Faranak Akhtarkhavari and Secretary, Department of Family and Community Services the Department's advocate, submitted that the applicant's ownership of two motor vehicles, the second purchased after the applicant had received notification of the debt, was conclusive evidence that the applicant was not eligible [58: Kiosoglous SM [26]]. The AAT disagreed and found that notwithstanding multiple motor vehicle ownership there were 'special circumstances' to waive the debt [58: Kiosoglous SM [58]]. For some applicants the fact of owning any motor vehicle was sufficient to justify a finding of un-deservingness. The AAT told the applicant in Re Gary James Anderson and Secretary, Department of Family and Community Services that he would be more likely to be granted social security if he sold his 16 year old Ford Laser and make 'the proceeds of sale last for several weeks at least' [59: Blow DP [20]]. However, the suggestion raised in that decision that ownership of any motor vehicle evidenced un-deservingness was not common. Instead, what was very common was a reading of the make and model of applicant's motor vehicle according to criteria of deservingness.

In Re Secretary, Department of Family and Community Services and David Andrew Cawthorn the applicant had sold his aging Subaru and purchased a new $\$ 50,000$ BMW when he received a compensation payment. The applicant argued that: 'on the issue of having a BMW motor car, he said

\footnotetext{
${ }^{11}$ See also Re Bradley Bayfield and Secretary, Department of Family and Community Services [49: Webb M [43]] and Re Douglas Doelle and Secretary, Department of Family, Housing, Community Services and Indigenous Affairs [57: Karas SM [5]].
} 
it was regarded as being a safe and reliable car with wide doors which permits adequate access for his wheelchair' [99: Handley SM [56]]. The AAT disagreed. It found that the applicant's ownership of a BMW was strong evidence that he did not have 'special circumstances' [99: Handley SM [84]]. Indeed, owners of recently purchased motor vehicles from prestige German manufactures were considered undeserving of social security. The language of the AAT when describing applicants who had purchased Mercedes Benzes on receiving compensation payouts was strikingly moralistic. The applicant who purchased a $\$ 60,000$ Mercedes was described as 'reckless' [63: Levy SM [38]]. Another applicant who spent nearly $\$ 300,000$ on several Mercedes motor vehicles was 'extravagant' and 'lavish' [60: Isenberg SM [21], [29]]. It seems from this language that the Australian equivalent to the Cadillac driving welfare queen is the Mercedes owning compensation recipient. However, what further emerges from the sample is that there are other vehicles that attract this moral condemnation.

Studies in motor vehicle semiotics have identified a set of negative associations attached to SUVs and their drivers. Connotations such as 'uncaring', 'selfish' and 'aggressive' have been identified [31: 23]. Within the AAT decisions these negative associations buttressed findings that applicants were not eligible for social security. Applicants with large SUVs like Toyota Land Cruisers [100], Jeep Grand Cherokees [93], [81] and Range Rovers [71] and also applicants who purchased four-wheel-drive twin cab utilities [50] were found to be undeserving. ${ }^{12}$ Applicants who bought SUVs were described as 'reckless' [56: Cunningham SM [25] (Toyota Parado)]. Arguments that these vehicles were needed because their ride height made it easier for mobility impaired applicants to enter and leave the vehicle or that an applicant needed a vehicle that could transport their large family were generally brushed aside. ${ }^{13} \mathrm{~A}$ similar set of negative connotations about un-deservingness were attached to applicants who owned large and powerful V6 and V8 sedans. The decision by applicants to purchase new Holden Commodores in particular was considered 'unreasonable' [87: Ermert M [22]], 'reckless' [89: Cunningham SM [10]] and 'excessive' [89: Cunningham SM [10], 76: Walsh SM [51]]. A final category of vehicle that suggested un-deservingness was sports cars [55]. An

\footnotetext{
${ }^{12}$ See also Re Qx2006/11 and Secretary, Department of Employment and Workplace Relations [85] (Nissan Pathfinder) and Re Lyn Rose and Secretary, Department of Employment and Workplace Relations [74] (replaced an old Ford Fairlane with a new SUV).

${ }^{13}$ In Re Murray and Secretary to the Department of Family and Community Services the 'Tribunal concludes that a second-hand vehicle, other than a Jeep Grand Cherokee would have accommodated the applicant's wheelchair' [81: Friedman M [21]]. In Re Secretary, Department of Family and Community Services and Max Lazarus the expenditure on a Toyota Land Cruiser to transport a family of six went against the applicant [100: Campbell M [40]]. On this see also Re Bradley Neilsen and Secretary, Department of Education, Employment and Workplace Relations [50]. There was a decision were an applicant had an SUV and was not seen as undeserving. In Re Secretary, Department of Employment and Workplace Relations and Harry Ludwig Ragitsch the applicant had no principal place of residence and otherwise resided in his car and caravan. The AAT accepted that he needed an SUV to tow the caravan [95].
} 
applicant who purchased a Toyota Celica was described as 'ill-considered' [67: Webb M [11]] The social security debt of an applicant with a 14 year old Nissan Skyline GTS was pointedly not waived [82: Fice M [31-32]]. So too the social security debts of the Mazda RX7 and Porsche owning applicant in Re Janina Bacea and Secretary, Department of Education, Employment and Workplace Relations were affirmed [62]. In each of these decisions the AAT found that the applicants had not been reckless but actively dishonest in their dealings with the Department [82: Fice $M$ [31-32], 62: Sweidan SM [63]]. The image of the sport car driver as an unreliable risk taker [31: 31] was a strong subtext.

From these decisions it can be summarised that social security applicants who have motor vehicles from German prestige marques, or SUVs, or large V6 and V8 powdered sedans or sport cars have been considered by the AAT to be undeserving of social security. One possible extrapolation from this data could be that the AAT is dictating that any social security applicant who owns a new or near-new motor vehicle renders them undeserving for social security. This could be seen affirming the previously identified assumption that if social security applicants were to own motor vehicles they had to be old and rundown. This would be the case if it was not for a cluster of decisions where the purchase of certain motor vehicles was considered prudent.

In Re Laurence Maloney and Secretary, Department of Family and Community Services the applicant sold his old utility vehicle and purchased a small Hyundai [72: McCabe M [6]]. The explanation for the purchase was that this new vehicle was more suitable for the applicant's disabled partner. The AAT found that the purchase of the vehicle was 'modest' [72: McCabe M [23]] and that 'special circumstances' did exist for the applicant to receive social security. In particular the AAT felt that compelling the applicant to sell the car would contribute to the applicant 'taking a one way ticket to poverty' [72: McCabe M [27]]. Indeed, purchasing certain cars was seen by the AAT as a prudent choice, bolstering the applicant's deservingness for social security. What mattered were the meanings attached to the make and model of car. The 'approved' vehicles were small, economical, cheap front wheel drive cars from Korean ${ }^{14}$ or Japanese ${ }^{15}$ manufactures. In other words, the approved cars were vehicles that communicated opposite meanings than the vehicles that signified un-deservingness. The AAT considered buying a second-hand Hyundai with compensation

\footnotetext{
${ }^{14}$ Re Stanley Brady and Secretary, Department of Employment Workplace Relations [104: McDermott SM [64]] (a 7 year old Hyundai), Re Joan Mary Chamberlain and Secretary, Department of Family And Community Services [65: McCabe M [10]] (Hyundai Excel), Re Robina Abdel-Fadeel and Secretary, Department of Family and Community Services [92: Handley DP [10]] (Hyundai Getz).

${ }^{15}$ Re Lilly Harmat and Department of Family and Community Services [73: Handley SM [11]] (Mitsubishi Lancer), Re Abdulkader Ayad and Secretary, Department of Family and Community Services [45: Handley SM [11]] (Ford Laser - a rebadged for the Australian market Mazda 323), Re Jelena Djakovic and Secretary, Department of Family and Community Services [64: Bell M [6]] (Honda Prelude).
} 
money could 'not be regarded as an extravagant purchase' [104: McDermott SM [89]]. In another decision the purchase of a Hyundai Excel was 'a reasonable response to the difficulties in accessing public transport' [65: McCabe M [25]]. The giving away a 'rusty old car' and spending $\$ 15,000$ on a near new Ford Laser was 'reasonably necessary' and 'not extravagant' [45: Handley SM [47]]. Purchasing a new 'inexpensive small car - a Hyundai Getz' was considered 'entirely responsible' [92: Handley DP [14], [27]]. Applicants that downgraded from large and expensive to operate vehicles to new, small and fuel efficient vehicles were equally considered prudent. ${ }^{16}$ The applicant in Re Trent Barrington and Secretary, Department of Employment and Workplace Relations who successively downgraded from a new Subaru Outback to a second-hand Holden Commodore and then downgraded further to a 28 year old Subaru was described as 'quite frugal and prudent' [107: Groom DP [11], [38]]. Also seen as prudent were applicants who spent windfalls on repairing their existing vehicle rather than purchasing new [69: Webb M [16], [27]].

Together what these decisions show is that the car avatar is decoded by the AAT into constitute meaning streams concerned with deservingness and prudence. Applicants with old and rundown motor vehicles were seen as more deserving then applicants who owned several motor vehicles or expensive new motor vehicles. Applicants whose car avatar suggested excessiveness - in the form of a vehicle from a prestige German manufacturer, a SUV, a powerful large sedan or a sports car - were considered 'reckless' and not deserving. However, applicants with small, economical Asian manufactured vehicles were generally seen as prudent and more deserving.

Within the sample the car did more than just be an asset value or a gauge of an applicant's mobility. At times the slippages between car and applicant, the mechanics behind the formation of the car avatar was express with the decisions. The car/applicant had been seen and recorded; another's car had been observed parked on the applicant's property; data had been found linking car, applicant and another. In other decisions the car avatar was presumed and then decoded. It was presumed that the car revealed details about the applicant. Social meanings about the condition, the make and model were then transposed into moral discourse about deservingness and prudence.

\section{Legality and Automobility}

\footnotetext{
${ }^{16}$ In Re Charles Dean and Secretary, Department of Employment and Workplace Relations the applicants replaced a Ford Falcon with a new small Kia and the AAT approved of their 'financial responsibility and good management of their limited resources' [52: Hunt SM [6], [30]]. In Re Colin Shovan and Secretary, Department of Education, Employment and Workplace Relations an applicant who downgraded from a large SUV (Nissan Patrol) to a smaller car was considered prudent and deserving [53].
} 
What does this all mean? At the pragmatic level for Australian social security applicants and their advocates it suggests awareness and caution when it comes to motor vehicles. Single applicant's should not let 'friends' store vehicles on their property and should not have other people's name on the registration databases. For applicants with two cars or who own a vehicle from the 'reckless and excessive' categories, the message seems particularly clear. While the decisions do seem to point to a general principal that Australian social security applicants are permitted to have $a$ motor vehicle, prudent and deserving applicants own old and rundown vehicles or if they have a newer vehicle it is a small and economical car from an Asian manufacturer. This seems commonsensical. By definition within an automobile culture the everyday semiotics of motor vehicles will leech into other social fields. However, in that very statement two remarkable processes can be identified.

The first is the remarkable process whereby the decisions capture the life of the applicant within text. Bruno Latour in his study of the Conseil d'Etat was intrigued by the textual processes whereby law and facts generate decision [35]. While the AAT is not the Conseil d'Etat there are some particular similarities between the two institutions. Both belong formally within the executive and not the judiciary [35: 34-44]. Both are staffed by decision makers who might not have formal legal training or experience and both are generalist review entities hearing appeals from diverse administrative agencies and portfolios [35: 111-114]. There are significant differences, while the Conseil d'Etat is a final decision maker within French administrative law the AAT sits in the shadows of the Australian federal court hierarchy which can judicially review AAT decisions for errors of law [3: s 44.]

However, Latour's observation of the textuality of judgment can be identified in the AAT decisions. Latour identified a process of 'bridging' whereby stacks of texts that concerned the facts and stacks of texts that concerned the law were carefully brought together in the successive texts drafted by councillors of the Conseil d'Etat [35: 86-87]. For Latour the final decision showed the traces of this stacking and bridging [35: 88]. The 'facts' became purified, organised and arranged according to the legal principal; while the 'law' was refined and narrowed according to the facts. This 'physical work of intertextuality that is necessary for the material fabrication of judgment' [35: 92] was highly present within the AAT decisions. Under a legislative compulsion to organise its decisions to show the evidence, the facts and the application of the facts to the law [3: s43(2B)], the AAT decisions formed impressive bridges. Headings and subheadings abound. The evidence presented by the applicant at the hearing was summarised followed by the evidence presented by the Department. This building of the factual stack was not purely descriptive. There was a weighing and 
testing of the evidence, a deciding that applicant and witness testimony was credible or not, a reading of documents in files, statements, videos, entries from databases, to see what they say. Facts were shaped and identified. But this was not a sui generis process of truth determination for truth's sake. It was partial and purposeful in its reaching towards the law. A similar process can be identified in text that stands as testimony to the law stack. The law was determined; the intricacies of the member of a couple rule, or past AAT or Federal Court decisions that have interpreted 'special circumstances' were canvassed. But again this was not just description, it was a shaping. The pure text of the Social Security Act 1991 (Cth) became expanded through the inclusion of more texts and in this expansion it reached out towards the facts; then came the reasons for the decision proper, Latour's deck of the bridge. There was a rush. Usually in a few paragraphs judgment was delivered, the bridge was crossed, and the decision under appeal was affirmed or remade.

An observation that Latour makes through this 'echographies' [19: 69] of the text of a legal judgment concerns the movements and transformations of the mundane and every day through the rarefied realms of law. He observes how within the Lebon, the formal report of the Conseil d'Etat, there are 'ski slopes' and 'dustbins' [35: 268] but simultaneously they are not present: 'A social life depended on the Lebon...would be pretty miserable' [35: 269]. Law does not replace life; but 'it formats' [35: 268]. Law depends on life for its own life, needing the totality of the world to give it actors and languages, texts and problems [35: 269]; while at the same time law imposes onto life, changing the flows of actors and languages, texts and problems [35: 258-9]. What this sample of AAT decisions showed was these transformations of life and law. The mundane and often sordid bits and pieces of an applicant's life were ordered and arranged to show, or not to show a relationship or a special circumstances. For example at paragraph 80 of Re WVXS and Secretary, Department of Education, Employment and Workplace Relations and Secretary, Department of Families, Housing, Community Services and Indigenous Affairs Deputy President Constance notes:

On 4 June 2004 [an investigator] followed the Applicant driving a Commodore motor vehicle from the home to a nearby service station. The Applicant was observed refuelling the car while Mrs $M$ was sitting in the front passenger seat. The vehicle was then driven to business premises where the Applicant alighted. Mrs M was observed to drive the vehicle back to the home [110: Constance DP [80]].

Notwithstanding, these representations of mobile togetherness, Deputy President Constance finds at paragraph 118 that the applicant was not a 'member of a couple' with Mrs M [110: Constance DP [118]]. Potentially the observed bodies within the Commodore showed a relationship in 2004 but not for the actual periods from 1995 to 2001 that were under review. As such the decision by the 
Department that the applicant owed a debt comprising the amounts incorrectly paid at the single rate during the review period was set aside [110: Constance DP [120]].

This taking from life into law - of not only text documenting surveillance but at paragraph 81 the Deputy President records that there was a video of the events described in paragraph 80 [110: Constance DP [81]] - could be read in alarmist terms. Following Giorgio Agamben it could be suggested that this surveillance and documenting of an applicant's life reveals the dehumanising machinations of the biopolitical state [5]. The decision clinically documents a human body where the classic legal and political rights of modernity - rights to privacy, freedom of movement and freedom of association - seemingly have been stripped away. The applicant has been left bare; his name might be flimsily hidden by a pseudonym but the details of his marital conflict, his changing residences, the relationships with his children, his criminal court appearances, health issues, and his various motor vehicle ownerships are public, there for all to read. In Agamben terms bios has become zoe [5: 188]. But it is not the biological fleshy animal of a human that is in focus in paragraph 80. The bodies of the applicant and Mrs M are not known and naked, they are not exposed open and ready for the application of bio-techniques of control and management, but enclosed and moving. They are in the Commodore. The applicant is driving. They travel along roads. They perform the everyday ritual of refuelling the car at a service station. They travel to another address. The applicant leaves the car. Mrs M moves to the drivers seat and then drives the vehicle to the residence. These are technologically augmented bodies purposively doing-in-the-world. The car avatar and the users combine to move and do. It is not so much as bios to zoe but Agamben's actual point of the indistiguishableness of bios and zoe [5: 188]. The decisions by the AAT in the sample concerning payments under the Social Security Act 1991 (Cth) are, but then are not, decisions about a human's legal entitlements. Rather they are processes where flows, relationships and networks and particularly the social meanings generated by specific relationships between humans and certain makes and models of cars - have been caught by texts that have then been stacked and bridged to make a final text in which life is then formatted. Debts are raised and debts are cancelled. Payments are made and then cancelled. Relationships are made and cancelled, and cars identified as surplus to be sold.

This leads to the second remarkable process. As an examination of automobile semiotics the study reveals that, in Australia, there are strong preconceptions about the 'morality' of drivers of certain motor vehicles. People with old cars are allowed to be on social security. Further, there seemed to be a strong positive association that owners of newer small, fuel efficient Asian manufactured hatchbacks are sensible and prudent and likewise deserve state support. This positive 
association was in opposition to a variety of vehicles that signified recklessness and lack of prudence. People who had owned vehicles from prestigious German manufactures, or SUVs or large and powerful V6 and V8 powered Australian made sedans or sports cars were regarded as undeservingness. In this study the AAT can be seen to be channelling a wider taxonomy of cultural meanings concerning specific makes and models of motor vehicles; that certain vehicles say certain things about the driver.

What this study of social security appeals in the AAT further shows for automobility is the mundane totality of automobile culture. The sample reveals how the car avatar and the meanings to be drawn from motor vehicles go beyond the highways and the media streams; the two sites that have been the focus of automobile semiotics. To adopt a rather old and well breached distinction, the decisions show these aspects of automobile culture are not just in the 'private' zone of prejudices and desires about the status, class, gender and age of the human driver of certain makes and models, but pass into the public realm of law and judgment. In other words 'cars as communication' [27] is not just a frivolous feature of living with the car in the West but has become entwined in the very processes of governance [121]. Cars were not quarantined in the decisions as assets to be valued, they did more. They become avatars from which judgments of deserving and underserving-ness could be made that allowed life to become formatted. For automobility what has been shown is the way that cars, not just as transportation technologies, but their social meanings have become integrated into the processes of judgment. The biopolitical machinery in the West does not process humans as zoe but sees and reads hybrids of machine, flesh and data. It evidences the totality of automobile culture; for within that dark heart of law, the site of judgement where the abstract become real in formatting life through the determination of rights and entitlements, two headlights shine.

\section{Conclusion}

This paper argued, through an examination of 145 AAT decisions, that the car in Australian social security law is not just an asset whose monetary value goes towards tests for eligibility, but becomes an avatar for the applicant that is decoded into meaning streams concerning deservingness and prudence. It was suggested that this examination of a less than obvious site of law and automobility had two implications. First it highlighted the techniques where by a technical object (the car) and the 'life' of the applicant became bridged in law; and through that bridging life is formatted. The second, for automobility, it highlighted the extent of automobile culture; in that social meanings about cars go beyond the highways and parking lots and have been integrated into the processes of biopolitical governance. 


\section{Appendix}

Table 1: Vehicles by Manufacturer in Sample

\begin{tabular}{|c|c|}
\hline Manufacturer & Frequency in Sample \\
\hline Toyota & 40 \\
\hline Ford & 34 \\
\hline General Motors Holden & 34 \\
\hline Nissan & 14 \\
\hline Hyundai & 12 \\
\hline Mitsubishi & 10 \\
\hline Mercedes Benz & 7 \\
\hline BMW & 5 \\
\hline Honda & 5 \\
\hline Subaru & 5 \\
\hline Mazda & 4 \\
\hline Jeep & 3 \\
\hline Rolls Royce & 3 \\
\hline Volvo & 2 \\
\hline Suzuki & 2 \\
\hline Range Rover & 1 \\
\hline Porsche & 1 \\
\hline Saab & 1 \\
\hline Volkswagen & 1 \\
\hline Bedford & 1 \\
\hline Kia & 1 \\
\hline Not Named/Motorcycle & 30 \\
\hline Total & 216 \\
\hline
\end{tabular}

\section{References}

1. Administrative Appeals Tribunal 2010 Annual Report 2009-2010 Administrative Appeals Tribunal Canberra.

2. Administrative Appeals Tribunal 2012 Annual Report 2011-2012 Administrative Appeals Tribunal Canberra.

3. Administrative Appeals Tribunal Act 1975 Commonwealth of Australia. 
4. Administrative Review Council 1995 Better Decisions: A Review of Commonwealth Merits Review Tribunals Administrative Review Council Canberra.

5. Agamben, Giorgio. 1998. Homo Sacer: Sovereign Power and Bare Life. Trans. Daniel Heller-Roazen. Crossing Aesthetics. Stanford: Stanford University Press.

6. Australasian Legal Information Institute. 2013. AUSTLII. http://www.austlii.edu.au/. Accessed 3 September 2013.

7. Australian Bureau of Statistics 2013 Motor Vehicle Censues Australian Bureau of Statistics 9309.0 Canbera.

8. Böhm, Steffen, Campbell Jones, Chris Land, and Matthew Paterson. 2006. Introduction: Impossibilities of Automobility. In Against Automobility, eds. Steffen Böhm, and Campbell Jones, and Chris Land, and Matthew Paterson, 3-16. Oxford: Blackwell.

9. Butler, Chris. 2008. Slicing Through Space: Mobility, Rhythm and the Abstraction of Modernist Transport Planning. Griffith Law Review: A Journal of Social and Critical Legal Studies 17 (2):470-488.

10. Carney, Terry. 2006. Social Security Law and Policy. Leichhardt: Federation Press.

11. Cassiman, Shawn A. 2008. Resisting the Neo-liberal Poverty Discourse: On Constructing Deadbeat Dads and Welfare Queens. Sociology Compass 2 (5):1690-1700.

12. Castronova, Edward. 2003. Theory of the Avatar. In CESifo Working Paper.

13. Castronova, Edward. 2006. Synthetic Worlds: The Business and Culture of Online Games. Chicago: Chicago University Press.

14. Clarsen, Georgine. 2009. Mobility in Australia: Unsettling the Settled. In Mobility in History: The State of the Art in the History of Transport, Traffic and Mobility, eds. Gijs Mom, and Gordon Pirie, and Laurent Tissot, 123-128. Neuchatel: Editions Alphil - Presses Universitaires Suisses.

15. Clarsen, Georgine. 2011. Automobility 'South of the West': Towards a Global Conversation. In Mobility in History: Themes in Transport, eds. Gijs Mom, and Peter Norton, and Georgine Clarsen, and Gordon Pirie, 25-41. Neuchatel: Editions Alphil - Presses Universitaires Suisses.

16. Coleman, Beth. 2011. Hello Avatar: Rise of the Networked Generation. Cambridge, MA: MIT Press.

17. Davison, Graeme. 2004. Car Wars: How the Car Won our Hearts and Conquered our Cities Crows Nest: Allen and Unwin.

18. Department of Human Services. 2013. Guide to Australian Government Payments 1 July-19 September 2013. Canberra: Department of Human Services.

19. Derrida, Jacques, and Bernard Stiegler. 2002. Echographies of Television. Trans. Jennifer Bajorek. Cambridge: Polity. 
20. Divall, Colin, and George Revill. 2005. Cultures of Transport: Representation, Practice and Technology. Journal of Transport History 26 (1):99-111.

21. Doob, Anthony, and Alan Gross. 1968. Status of Frustrator as an Inhibitor of Horn-Honking Responses. Journal of Social Psychology 76:213-218.

22. Dunn, Robert A, and Rosanna E Guadagno. 2013. My Avatar and Me - Gender and Personality Predictors of Avatar-self Discrepancy. Computers in Human Behavior 28 (1):97-106.

23. Edsensor, Tim. 2004. Automobility and National Identity. Theory, Culture and Society 21 (4/5):101-120.

24. Flink, James J. 1970. America Adopts the Automobile, 1895-1905. Cambridge, Massachusetts: The MIT Press.

25. Freund, Peter, and George Martin. 2009. The Social and Material Culture of Hyperautomobility: "Hyperauto". Bulletin of Science, Technology and Society 29 (6):476-482.

26. Gartman, David. 2004. Three Ages of the Automobile: The Cultural Logics of the Car. Theory, Culture and Society 21 (4/5):169.

27. Giblett, Rod. 2000. Magician's Bower: The Car as Communication Technology. Australian Journal of Communication 27 (2):15-24.

28. Gjøen, Heidi, and Mikael Hård. 2002. Cultural Politics in Action: Developing User Scripts in Relation to the Electric Vehicle. Science, Technology and Human Values 27 (2):262-281.

29. Graves-Brown, Paul. 2000. Always Crashing the in the Same Car. In Matter, Materiality and Modern Culture, ed. Paul Graves-Brown. London: Routlege.

30. Heffner, Reid R, Kenneth S Kurani, and Thomas S Turrentine. 2007. Symbolism in California's Early Market for Hybrid Electric Vehicles. Transportation Research Part D 12:396-413.

31. Heffner, Reid R, Thomas S Turrentine, and Kenneth S Kurani 2006 A Primer on Automobile Semiotics University of California, Davis UCD-ITS-RR-06-01 Davis California.

32. Huddy, Xenophon P. 1905. The Motor Car's Status. Yale Law Journal 15:83-86.

33. Kitson, Michael. 2003. The Great Aussie Car Smash at the End of the World. Australian Screen Education 31:64-69.

34. Knott, John William. 1994. Speed, Modernity and the Motor Car: The Making of the 1909 Motor Traffic Act in New South Wales. Australian Historical Studies 26 (113):221-224.

35. Latour, Bruno. 2010. The Making of Law: An Ethnography of the Conseil d'Etat London: Polity.

36. LexisNexis. 2013. Motor Vehicle Reports Online. http://www.lexisnexis.com.au/enau/products/motor-vehicle-reports-online-Inau-platform-only.page. Accessed 8 September 2013. 
37. Lochlann Jain, Sarah S. 2004. "Dangerous Instrumentality": The Bystander as Subject in Automobiliy. Cultural Anthropology 19 (1):61.

38. Lochlann Jain, Sarah S. 2005. Violent Submission. Cultural Critique 61:186-214.

39. Luckin, Bill, and David Sheen. 2009. Defining Early Modern Automobility. Cultural and Social History 6 (2):211-230.

40. Meadows, Mark Stephen. 2008. I, Avatar: The Culture and Consequences of Having a Second Life. Berkeley, California: New Riders.

41. Merriman, Peter. 2009. Automobility and the Geographies of the Car. Geography Compass 3 (2):586-599.

42. Myers, Margaret, and Sharon G Dean. 2007. "Cadillac Flambé": Race and Brand Identity. In Proceedings of the 23rd. Conference on Historical Analysis and Research in Marketing. Durham, North Carolina.

43. Noble, Greg, and Rebecca Baldwin. 2001. Sly Chicks and Troublemakers: Car Stickers, Nonsense and the Allure of Strangeness. Social Semiotics 11 (1):75-89.

44. Plowden, William. 1973. The Motor Car and Politics in Britain 1896-1970. Harmondsworth: Penguin Books.

45. Re Abdulkader Ayad and Secretary, Department of Family and Community Services [2000] AATA 102.

46. Re Alexandra Harvey and Secretary, Department of Education, Employment and Workplace Relations [2011] AATA 23.

47. Re Angela Katherine Direen and Secretary, Department of Employment and Workplace Relations [2006] AATA 935.

48. Re Bernard Charles Griffin-Beale and Secretary, Department of Family and Community Services [2003] AATA 1002.

49. Re Bradley Bayfield and Secretary, Department of Family and Community Services [2005] AATA 161.

50. Re Bradley Neilsen and Secretary, Department of Education, Employment and Workplace Relations [2012] AATA 591

51. Re Brett Matthew Cashion and Secretary, Department of Family and Community Services [2002] AATA 425.

52. Re Charles Dean and Secretary, Department of Employment and Workplace Relations [2006] AATA 932.

53. Re Colin Shovan and Secretary, Department of Education, Employment and Workplace Relations [2009] AATA 748. 
54. Re Craig Whittier Cornish and Secretary, Department of Family and Community Services [2003] AATA 91.

55. Re Deborah Ryan and Secretary, Department of Families, Housing, Community Services and Indigenous Affairs [2008] AATA 1126.

56. Re Department of Families, Community Services and Indigenous Affairs and Adam Smith [2012] AATA 262.

57. Re Douglas Doelle and Secretary, Department of Family, Housing, Community Services and Indigenous Affairs [2008] AATA 684.

58. Re Faranak Akhtarkhavari and Secretary, Department of Family and Community Services [2000] AATA 55.

59. Re Gary James Anderson and Secretary, Department of Family and Community Services [2000] AATA 431.

60. Re Ian Hamilton and Secretary, Department of Families, Housing, Community Services and Indigenous Affairs [2010] AATA 282.

61. Re Ildo Marinozzi and Secretary, Department of Family and Community Services [2003] AATA 456.

62. Re Janina Bacea and Secretary, Department of Education, Employment and Workplace Relations [2008] AATA 1080

63. Re Jann Ford and Secretary, Department of Families, Housing, Community Services and Indigenous Affairs [2012] AATA 288.

64. Re Jelena Djakovic and Secretary, Department of Family and Community Services [2001] AATA 1003.

65. Re Joan Mary Chamberlain and Secretary, Department of Family And Community Services [2002] AATA 487.

66. Re Joao De Sousa and Secretary, Department of Family and Community Services [2002] AATA 391.

67. Re John Charles and Secretary, Department of Education, Employment And Workplace Relations [2009] AATA 666.

68. Re Joseph Cutajar and Carmen Cutajar and Secretary, Department of Family and Community Services [2000] AATA 588.

69. Re Karen Unterrheiner and Secretary, Department of Family and Community Services [2003] AATA 487.

70. Re Kathryn Farrugia Steven Baltis and Secretary, Department of Employment, Education and Workplace Relations [2008] AATA 810. 
71. Re Kevin Alan Shaw and Secretary, Department of Family and Community Services [2000] AATA 168.

72. Re Laurence Maloney and Secretary, Department of Family and Community Services [2002] AATA 320.

73. Re Lilly Harmat and Department of Family and Community Services [2000] AATA 661.

74. Re Lyn Rose and Secretary, Department of Employment and Workplace Relations [2006] AATA 642.

75. Re Mary Hopkins and Secretary, Department of Families, Housing, Community Services and Indigenous Affairs [2010] AATA 50

76. Re Mervyn Hodge and Secretary, Department of Families, Housing, Community Services and Indigenous Affairs [2010] AATA 808.

77. Re Michelle Lizars and Secretary, Department of Education, Employment and Workplace Relations [2009] AATA 742.

78. Re Milovan Nikolic and Secretary, Department of Family and Community Services [2001] AATA 736.

79. Re Mohamed Halabi and Secretary, Department of Family And Community Services [2004] AATA 1323.

80. Re Monica Terese Eime and Secretary, Department of Families, Housing, Community Services and Indigenous Affairs [2008] AATA 138.

81. Re Murray and Secretary to the Department of Family and Community Services [2003] AATA 641.

82. Re Paul Morcos and Secretary, Department Of Education, Science and Training [2007] AATA 1079.

83. Re Peter Holt and Secretary, Department of Education, Employment and Workplace Relations [2010] AATA 143.

84. Re QDGF and Secretary, Department of Employment and Workplace Relations [2007] AATA 1321.

85. Re Qx2006/11 and Secretary, Department of Employment and Workplace Relations [2006] AATA 969.

86. Re Rany Mao and Secretary, Department of Education, Employment and Workplace Relations [2009] AATA 818.

87. Re Richard Fitzgerald and Secretary, Department of Education, Employment and Workplace Relations [2008] AATA 271.

88. Re Rita Liszikam and Secretary, Department of Families, Community Services and Indigenous Affairs [2006] AATA 396. 
89. Re Robert Bruce Appleby and Secretary, Department of Families, Housing, Community Services and Indigenous Affairs [2011] AATA 173.

90. Re Robert Lemon and Secretary, Department of Families, Housing, Community Services and Indigenous Affairs [2010] AATA 250.

91. Re Robin Phillips and Secretary, Department of Families, Housing, Community Services and Indigenous Affairs [2012] AATA 85.

92. Re Robina Abdel-Fadeel and Secretary, Department of Family and Community Services [2004] AATA 161.

93. Re Rodney Jose Veness and Secretary, Department of Family and Community Services [2000] AATA 6.

94. Re Secretary, Department of Employment and Workplace Relations and Graham Inkster and Caterina Lelasi [2007] AATA 2019.

95. Re Secretary, Department of Employment and Workplace Relations and Harry Ludwig Ragitsch [2007] AATA 1339.

96. Re Secretary, Department of Families, Housing, Community Services and Indigenous Affairs and Agaton Balaj [2012] AATA 342.

97. Re Secretary, Department of Families, Housing, Community Services and Indigenous Affairs and Petra Schatz [2008] AATA 756.

98. Re Secretary, Department of families, Housing, Community Services and Indigenous Affairs and Vo Nguyen [2007] AATA 2075.

99. Re Secretary, Department of Family and Community Services and David Andrew Cawthorn [2002] AATA 1137.

100. Re Secretary, Department of Family and Community Services and Max Lazarus [2003] AATA 120.

101. Re Shane Jarvis and Secretary, Department of Education, Employment and Workplace Relations [2011] AATA 665.

102. Re Sharon Hodges and Secretary, Department of Employment and Workplace Relations [2006] AATA 255.

103. Re Silvia Rodriguez and Secretary, Department of Families, Housing, Community Services and Indigenous Affairs [2011] AATA 884.

104. Re Stanley Brady and Secretary, Department of Employment Workplace Relations [2005] AATA 1145.

105. Re Stephen Thomas and Secretary, Department of Family and Community Services [2003] AATA 842. 
106. Re Tracey Jane Day and Secretary, Department of Education, Employment and Workplace Relations [2009] AATA 415.

107. Re Trent Barrington and Secretary, Department of Employment and Workplace Relations [2005] AATA 1050.

108. Re Wafaa Gendy and Secretary, Department of Families, Housing, Community Services and Indigenous Affairs [2012] AATA 124.

109. Re WVXS and Secretary, Department of Education, Employment and Workplace Relations and Secretary, Department of Families, Housing, Community Services and Indigenous Affairs [2012] AATA 311.

110. Re WVXS and Secretary, Department of Education, Employment and Workplace Relations and Secretary, Department of Families, Housing, Community Services and Indigenous Affairs [2012] AATA 311.

111. The Red Book 2013. http://www.redbook.com.au/ Accessed Last accessed 2 September 2013.

112. Redshaw, Sarah. 2007. Articulations of the Car: The Dominant Articulations of Racing and Rally Driving. Mobilities 2 (1):121-141.

113. Redshaw, Sarah. 2008. In the Company of Cars: Driving as a Social and Cultural Practice. Aldershot: Ashgate.

114. Shi v Migration Agents Registration Authority (2008) 235 CLR 286 (High Court of Australia).

115. Simpson, Catherine. 2006. Antipodean Automobility and Crash: Treachery, Trespass and Transformation of the Open Road. Australian Humanities Review 39-49.

116. Sleep, Lyndal, Kieran Tranter, and John Stannard. 2006. Cohabitation Rule in Social Security Law: The More Things Change the More They Stay the Same. Australian Journal of Administrative Law 13 (3):135-146.

117. Social Security (Administration) Act 1999 Commonwealth of Australia.

118. Social Security Act 1991 Commonwealth of Australia.

119. Strauss, Richard. 1998. Up for Rego: A Social History of the Kingswood. Annadale: Pluto Press.

120. Sutherland, Peter, and with Allan Anforth. 2005. Social Security and Family Assistance Law. 2nd Aufl. Annandale: Federation Press and Welfare Rights Centre.

121. Tranter, Kieran. 2003. Mad Max: The Car and Australian Governance. National Identities 5 (1):67-81.

122. Tranter, Kieran. 2005. 'The History of the Haste-Wagons': The Motor Car Act 1909 (Vic), Emergent Technology and the Call for Law. Melbourne University Law Review 29 (3):843879. 
123. Tranter, Kieran, and Damien Martin. 2013. 'The Cutting Edge of Cocking About': Top Gear, Automobility and Law. Law and Humanities 7 (1):1-18.

124. Tranter, Kieran, Lyndal Sleep, and John Stannard. 2008. The Cohabitation Rule: Indeterminacy and Oppression in Australian Social Security Law. Melbourne University Law Review 32 (2):698-738.

125. Urry, John. 2004. The 'System' of Automobility. Theory, Culture and Society 21 (4/5):25-39.

126. Walsh, Margaret. 2008. Gendering Mobility: Women, Work and Automobility in the United States. History 93 (311):376-395.

127. Wetmore, Jameson M. 2009. Implementing Restraint: Automobile Safety and the US Debates over Technological and Social Fixes. In Car Troubles: Critical Studies of Automobility and Auto-Mobility, eds. Jim Conley, and Arlene Tigar McLaren, 111-125. Farnham, Surrey: Ashgate. 